\title{
The Phosphoenolpyruvate Carboxykinase of Verticillium albo-atrum
}

\author{
By R. E. HARTMAN \\ Department of Biology, St Bonaventure University, \\ St Bonaventure, New York, 14778, U.S.A. \\ AND N. T. KEEN \\ Department of Plant Pathology, University of \\ California, Riverside, 92502, U.S.A. \\ (Received 17 April 1973; revised 8 October 1973)
}

\begin{abstract}
SUMMARY
Partially purified phosphoenolpyruvate carboxykinase from Verticillium alboatrum had a $\mathrm{pH}$ optimum of 6.2 and required manganese for maximum activity, having lesser activity with iron or cobalt. Sodium and potassium ions were slightly stimulatory. Adenosine-5'-diphosphate increased activity and inosine-5'diphosphate supported low activity, but other nucleotides were ineffective. Inhibition of the enzyme by $p$-chloromercuribenzoate was partially reversed by dithiothreitol. Avidin had no effect on enzyme activity. Oxalacetate slightly stimulated the enzyme and NADP ${ }^{+}$strongly inhibited, but aspartate and acetylCoA showed no effect. Low levels of phosphoenolpyruvate carboxykinase were present in cells grown on glucose, xylose, or glycerol. Aspartate, pyruvate, and acetate as carbon sources resulted in higher levels of activity and malate gave the highest. The data indicate that the enzyme functions physiologically in the gluconeogenic conversion of oxalacetate to phosphoenolpyruvate.
\end{abstract}

\section{INTRODUCTION}

Carbon dioxide was utilized in the synthesis of aspartate, glutamate and nitrogen bases when the phytopathogenic fungus Verticillium albo-atrum was grown on glucose (Hartman, Keen \& Long, 1972). Growth did not occur in $\mathrm{CO}_{2}$-free atmospheres on glucose or glycerol media, but normal growth occurred on succinate or acetate. The suggested role of anaplerotic $\mathrm{CO}_{2}$-fixing enzymes was confirmed when Hartman \& Keen (I973) subsequently demonstrated the presence of pyruvate carboxylase (EC. 6.4 I I I) and phosphoenolpyruvate carboxykinase (PEPCK, EC. 4.I.I.32) in V.albo-atrum. On the basis of its properties and sensitivity to inhibition by aspartate and acetyl coenzyme $\mathrm{A}$, it was postulated that pyruvate carboxylase catalyses anaplerotic $\mathrm{CO}_{2}$ fixation in the fungus (Hartman \& Keen, 1974). To assess the role of PEPCK in the physiology of the fungus, we have studied its properties and determined the effect of various carbon sources on enzyme activity.

\section{METHODS}

Preparation of phosphoenolpyruvate carboxykinase. Verticillium albo-atrum, strain $\mathrm{V} 3 \mathrm{H}$ (ATCC26289), was grown and disrupted as previously described (Hartman \& Keen, 1973). Yeast-form cells were grown in a synthetic medium, washed, suspended in the tris breakage buffer (O. I M-tris; I.O mM-dithiothreitol; $0.1 \mathrm{mM}-\mathrm{Na}_{2}$ EDTA; $0 . \mathrm{I} \mathrm{M}-\mathrm{KCl}$; and $\mathrm{HCl}$ to $\mathrm{pH} 7.6$ ), 


\section{Table I. Effect of $\mathrm{pH}$ on the activity of phosphoenolpyruvate carboxykinase from Verticillium albo-atrum}

Reaction mixture: imidazole, $100 \mu \mathrm{mol} ; \mathrm{MnSO}_{4}, 2 \mu \mathrm{mol} ; \mathrm{KCl}, 100 \mu \mathrm{mol}$; phosphoenolpyruvate, Io $\mu \mathrm{mol}$; ADP, $5 \mu \mathrm{mol}$; $\mathrm{NaHCO}_{3}, 10 \mu \mathrm{mol}$; dithiothreitol, $5 \mu \mathrm{mol}$; $\mathrm{NaH}^{14} \mathrm{CO}_{3}, 5 \mu \mathrm{Ci}$; protein, $0.2 \mathrm{mg}$; $\mathrm{NaOH}$ to $\mathrm{pH}$ stated; total volume, $\mathrm{I} .5 \mathrm{ml}$. Incubation time: $10 \mathrm{~min}$.

$\begin{array}{cc}\mathrm{pH} & \begin{array}{r}\text { Radioactivity incorporated } \\ \text { (c.p.m. } 0.5 \mathrm{ml} \text { ) }\end{array} \\ 5 \cdot 2 & 1972 \\ 5 \cdot 8 & 9233 \\ 6 \cdot 2 & 13059 \\ 6 \cdot 9 & 6617 \\ 7 \cdot 3 & 3136\end{array}$

Table 2. Effect of cations on enzyme activity

Reaction mixture: imidazole, I00 $\mu \mathrm{mol}$; phosphoenolpyruvate, $10 \mu \mathrm{mol}$; ADP, $5 \mu \mathrm{mol}$; $\mathrm{KCl}$, $100 \mu \mathrm{mol}$; dithiothreitol, $5 \mu \mathrm{mol} ; \mathrm{KHCO}_{3}, \mathrm{IO} \mu \mathrm{mol}$; $\mathrm{NaH}^{14} \mathrm{CO}_{3}, 5 \mu \mathrm{Ci}$; protein, $0.2 \mathrm{mg}$; $\mathrm{NaOH}$ to $\mathrm{pH} 6 \cdot 2$; total volume, $1.5 \mathrm{ml}$. Incubation time: $10 \mathrm{~min}$.

$\begin{array}{lc}\begin{array}{l}\text { Cation } \\ (\mu \mathrm{mol})\end{array} & \begin{array}{r}\text { Radioactivity incorporated } \\ \text { (c.p.m. } / 0.5 \mathrm{ml})\end{array} \\ \mathrm{MnSO}_{4}(2) & 2 \mathrm{I} 190 \\ \mathrm{CoCl}_{2}(3) & 5394 \\ \mathrm{CaCl}_{2}(3) & 26 \\ \mathrm{FeSO}_{4}(3) & 9663 \\ \mathrm{ZnSO}_{4}(3) & 72 \\ \mathrm{MgSO}_{4}(3) & 208 \\ \text { None } & 26\end{array}$

and disrupted for I min in a Bronwill MSK homogenizer. The preparation was centrifuged for $10 \mathrm{~min}$ at $4{ }^{\circ} \mathrm{C}$ and $34000 \mathrm{~g}$.All procedures were carried out at approximately $4{ }^{\circ} \mathrm{C}$. To $10 \mathrm{ml}$ of supernatant was added solid ammonium sulphate $(3 . \mathrm{I} 3 \mathrm{~g})$ to achieve $50 \%$ saturation $\left(23^{\circ} \mathrm{C}\right)$. The precipitate was removed by centrifugation and $\mathrm{I} \cdot 25 \mathrm{~g}$ of solid ammonium sulphate was added to achieve $70 \%$ saturation $\left(23^{\circ} \mathrm{C}\right)$. The precipitate was

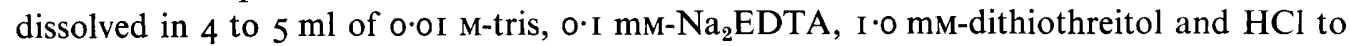
$\mathrm{pH} 7 \cdot 6$, and dialysed against the same buffer. The preparation represented a fourfold purification of the enzyme compared with the dialysed crude cell extract and fixed approximately $0.12 \mu \mathrm{mol}$ of $\mathrm{CO}_{2}$ (from $\mathrm{HCO}_{3}^{-}$) per min per mg protein.

Assay methods. Protein was estimated by the method of Lowry, Rosebrough, Farr \& Randall (195I) with bovine serum albumin as the standard. Enzyme activity was measured on the basis of the fixation of $\mathrm{NaH}^{14} \mathrm{CO}_{3}$ (Hartman \& Keen, I973). The specific activity of the $\mathrm{NaH}^{14} \mathrm{CO}_{3}$ was $50 \mathrm{mCi} / \mathrm{mm}$. A ro min incubation period was used to determine enzyme activity; fixation was shown to be linear with respect to time during the first Io $\mathrm{min}$.

\section{RESULTS}

The optimal $\mathrm{pH}$ for PEPCK from Verticillium albo-atrum was approximately $6 \cdot 2$ (Table I). Substitution of uridine-5'-diphosphate (UDP) or guanosine- $5^{\prime}$-diphosphate (GDP) for adenosine- $5^{\prime}$-diphosphate (ADP) in the reaction mixtures gave no activity, while inosine5 -diphosphate (IDP) supported only $12 \%$ of the activity with ADP at the optimum $\mathrm{pH}$.

Manganese was the most effective divalent cation in supporting PEPCK activity 


\section{Table 3. Effect of $\mathrm{pH}$ on the relative effectiveness of magnesium and manganese on enzyme activity}

Reaction mixture: imidazole, $100 \mu \mathrm{mol}$; phosphoenolpyruvate, $10 \mu \mathrm{mol}$; ADP, $5 \mu \mathrm{mol}$; $\mathrm{KCl}$, I00 $\mu \mathrm{mol}$; dithiothreitol, $5 \mu \mathrm{mol}$; $\mathrm{KHCO}_{3}$, Io $\mu \mathrm{mol}$; $\mathrm{NaH}^{14} \mathrm{CO}_{3}, 5 \mu \mathrm{Ci}$; protein, $0.2 \mathrm{mg}$; $\mathrm{NaOH}$ to $\mathrm{pH}$ stated; final volume, $\mathrm{I} \cdot 5 \mathrm{ml}$.

Divalent cation added
$(\mu$ mol $)$
None
$\mathrm{MnSO}_{4}(2)$
$\mathrm{MgSO}_{4}(3)$
$\mathrm{MnSO}_{4}(2)$
$\mathrm{MgSO}_{4}(3)$
$\mathrm{MnSO}_{4}(2)$
$\mathrm{MgSO}_{4}(3)$

Reaction mixture
pH
$6 \cdot 1$
$6 \cdot 1$
$6 \cdot 1$
$6 \cdot 8$
$6 \cdot 8$
$7 \cdot 4$
$7 \cdot 4$
Radioactivity incorporated
(c.p.m. $/ 0.5 \mathrm{ml}$ )

$$
\begin{array}{r}
140 \\
25453 \\
90 \\
15685 \\
902 \\
3870 \\
770
\end{array}
$$

Table 4. Effect of potassium, sodium and bicarbonate on enzyme activity

Reaction mixture: imidazole, $100 \mu \mathrm{mol}$; phosphoenolpyruvate, $10 \mu \mathrm{mol}$; ADP, $5 \mu \mathrm{mol}$; $\mathrm{KCl}$, $100 \mu \mathrm{mol} ; \mathrm{MnSO}_{4}, 2 \mu \mathrm{mol}$; dithiothreitol, $5 \mu \mathrm{mol} ; \mathrm{NaH}^{14} \mathrm{CO}_{3}, 5 \mu \mathrm{Ci}$; protein, $0.2 \mathrm{mg}$; $\mathrm{NaOH}$ to $\mathrm{pH} 6.2$; total volume, $1.5 \mathrm{ml}$.

$\begin{array}{cc}\begin{array}{c}\text { Component(s) added } \\ (\mu \mathrm{mol})\end{array} & \begin{array}{r}\text { Radioactivity incorporated } \\ \text { (c.p.m. } / 0.5 \mathrm{ml})\end{array} \\ \mathrm{None} & 12713 \\ \mathrm{KCl}(\mathrm{IOO}) & 14862 \\ \mathrm{NaCl}(\mathrm{IOO}) & 14891 \\ \mathrm{NaHCO}(\mathrm{IO}) & 15249 \\ +\mathrm{KCl} & 16020\end{array}$

Table 5. Effect of biotin, avidin and acetyl coenzyme A on enzyme activity

Reaction mixture: imidazole, $100 \mu \mathrm{mol}$; phosphoenolpyruvate, $10 \mu \mathrm{mol}$; ADP, $5 \mu \mathrm{mol}$; $\mathrm{MnSO}_{4}$, $2 \mu \mathrm{mol} ; \mathrm{KCl}, 100 \mu \mathrm{mol} ; \mathrm{KHCO}_{3}$, $10 \mu \mathrm{mol} ; \mathrm{NaH}^{14} \mathrm{CO}_{3}, 5 \mu \mathrm{Ci}$; protein, $0.2 \mathrm{mg} ; \mathrm{NaOH}$ to $\mathrm{pH} 6 \cdot 2$; total volume, $1.5 \mathrm{ml}$.

$$
\text { Component(s) added }
$$

None
Biotin $(0.5 \mu \mathrm{g})$
Biotin + avidin (0.5 units)
Avidin
CoASAc $(0.5 \mu \mathrm{mol})$

Radioactivity incorporated (c.p.m. $0.5 \mathrm{ml}$ )

$$
\begin{aligned}
& 15063 \\
& 15368 \\
& 15050 \\
& 14924 \\
& 15846
\end{aligned}
$$

(Table 2). Less activity was observed with $\mathrm{Fe}^{2+}$ and $\mathrm{Co}^{2+}$, and $\mathrm{Mg}^{2+}$ supported little. A relationship between $\mathrm{pH}$ and the relative effectiveness of $\mathrm{Mn}^{2+}$ and $\mathrm{Mg}^{2+}$ was observed (Table 3). With $\mathrm{Mn}^{2+}$, enzyme activity decreased as the $\mathrm{pH}$ increased while with $\mathrm{Mg}^{2+}$ it increased.

The enzyme activity was slightly stimulated by the addition of either $\mathrm{K}^{+}$or $\mathrm{Na}^{+}$to the reaction mixture (Table 4). Acetyl coenzyme A, biotin or avidin did not affect activity (Table 5). Dithiothreitol had a slightly stimulatory effect on PEPCK, while p-chloromercuribenzoate completely inhibited activity (Table 6). The inhibition could be partially reversed by the addition of dithiothreitol. N-Methyl maleimide was only slightly inhibitory.

Of various glycolytic pathway intermediates tested, glyceraldehyde-3-phosphate and glycerate-2,3-diphosphate gave $35 \%$ inhibition (Table 7 ), and the citric acid cycle inter- 


\section{Table 6. Effect of sulphydryl reagents on enzyme activity}

Reaction mixture: imidazole, $100 \mu \mathrm{mol}$; phosphoenolpyruvate, $10 \mu \mathrm{mol}$; ADP, $5 \mu \mathrm{mol}$; $\mathrm{MnSO}_{4}$, $2 \mu \mathrm{mol} ; \mathrm{KCl}, 100 \mu \mathrm{mol} ; \mathrm{KHCO}_{3}, 10 \mu \mathrm{mol} ; \mathrm{NaH}^{14} \mathrm{CO}_{3}, 5 \mu \mathrm{Ci}$; protein, $0.2 \mathrm{mg}$; $\mathrm{NaOH}$ to $\mathrm{pH} 62$; total volume, $\mathrm{I} \cdot 5 \mathrm{ml}$. Where single reagents were added to the reaction mixture, they were added 3 min before the addition of $\mathrm{NaH}^{14} \mathrm{CO}_{3}$. In the reaction mixture containing the combination of reagents, the enzyme in the reaction mixture was exposed to $p$-chloromercuribenzoate for $3 \mathrm{~min}$ followed by the addition of dithiothreitol for $2 \mathrm{~min}$ before the addition of $\mathrm{NaH}^{14} \mathrm{CO}_{3}$.

$\begin{array}{lc}\begin{array}{l}\text { Sulphydryl reagent(s) added } \\ (\mu \mathrm{mol})\end{array} & \begin{array}{c}\text { Radioactivity incorporated } \\ \text { (c.p.m./0.5 ml) }\end{array} \\ \text { None } & \text { I3788 } \\ \text { Dithiothreitol (20) } & \text { I57I5 } \\ \text { N-Methyl maleimide (I.5) } & 11920 \\ \text { p-Chloromercuribenzoate (0.15) } & \text { I5 } \\ \text { + dithiothreitol } & 6880\end{array}$

\section{Table 7. Effect of metabolic intermediates on phosphoenolpyruvate carboxykinase activity}

Reaction mixture: imidazole, $100 \mu \mathrm{mol}$; phosphoenolpyruvate, Io $\mu \mathrm{mol}$; ADP, $5 \mu \mathrm{mol}$; $\mathrm{MnSO}_{4}$, $2 \mu \mathrm{mol} ; \mathrm{KCl}, 100 \mu \mathrm{mol}$; dithiothreitol, $5 \mu \mathrm{mol}$; $\mathrm{KHCO}_{3}, 10 \mu \mathrm{mol}$; $\mathrm{NaH}^{14} \mathrm{CO}_{3}, 5 \mu \mathrm{Ci}$; protein, $0.2 \mathrm{mg} ; \mathrm{NaOH}$ to $\mathrm{pH} 6.2$; total volume, I. $5 \mathrm{ml}$. Where $\mathrm{DL}$ compounds were used, $20 \mu \mathrm{mol}$ were added.

\begin{tabular}{|c|c|c|c|}
\hline $\begin{array}{l}\text { Intermediates added } \\
\qquad(10 \mu \mathrm{mol})\end{array}$ & $\begin{array}{l}\text { Radioactivity } \\
\text { incorporated } \\
\text { (percentage of } \\
\text { control)* }\end{array}$ & $\begin{array}{l}\text { Intermediates added } \\
\qquad(10, \mu \mathrm{mol})\end{array}$ & $\begin{array}{r}\text { Radioac } \\
\text { incorpo } \\
\text { (percent } \\
\text { contre }\end{array}$ \\
\hline Aspartate & 96 & $\beta-\mathrm{NAD}^{+}$ & 66 \\
\hline Oxalacetate & IIO & NADP+ & 97 \\
\hline Malate & 65 & Glycerol & \\
\hline Succinate & 83 & DL-Glycerol-3-P & \\
\hline Fumarate & 87 & DL-Glyceraldehyde-3-P & 66 \\
\hline Citrate & 66 & Glycerate-3-P & 88 \\
\hline DL-Isocitrate & 74 & Glycerate-2-P & 76 \\
\hline$\alpha$-Ketoglutarate & 82 & Glycerate-2,3-P, & 62 \\
\hline Glutamate & 94 & Fructose-6-P & 0 \\
\hline Alanine & 95 & Fructose- $1,6-P_{2}$ & 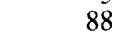 \\
\hline$\beta$-NADH & 86 & Glucose-I-P & \\
\hline NADPH & 65 & Glucose-6-P & \\
\hline
\end{tabular}

* The control value was the radioactivity obtained in the reaction mixture in the absence of the added intermediates. The radioactivity averaged about 25500 c.p.m. $0.5 \mathrm{ml}$ in the controls for the several experiments from which these data were obtained.

mediates malate and citrate also caused $35 \%$. The greatest inhibition, $63 \%$, was exhibited by NADP ${ }^{+}$, while the related cofactors, NADPH and $\mathrm{NAD}^{+}$, caused $35 \%$ inhibition. Although the stimulation by oxalacetate was only Io $\%$, it was consistent in several experiments (Table 7).

Malate was the most effective carbon source for activity of PEPCK in Verticillium albo-atrum (Table 8), followed by aspartate and then by pyruvate and acetate. The least effective carbon sources were glucose, xylose, and glycerol. When aspartate was tested, a small quantity of glucose was added to achieve an adequate quantity of cells.

\section{DISCUSSION}

The physiological role of PEPCK in Verticillium albo-atrum appears to be the gluconeogenic decarboxylation of oxalacetate to phosphoenolpyruvate. This hypothesis is supported by several observations. Although several glycolytic and Krebs-cycle inter- 
Table 8. Effect of carbon source on the activity of phosphoenolpyruvate carboxykinase in cells of Verticillium albo-atrum

Cells were grown in the carbohydrate $(5 \mathrm{~g} / \mathrm{l})$-ammonium nitrate $(2 \cdot 43 \mathrm{~g} / \mathrm{l})$-biotin medium, $\mathrm{pH} 6.3$ (Hartman, Keen \& Long, 1972) from a washed yeast-phase cell inoculum. Enzyme-assay reaction mixture: imidazole, $100 \mu \mathrm{mol}$; phosphoenolpyruvate, $10 \mu \mathrm{mol} ; \mathrm{ADP}, 5 \mu \mathrm{mol}$; $\mathrm{MnSO}_{4}, 2 \mu \mathrm{mol}$; $\mathrm{KCl}, 100 \mu \mathrm{mol}$; dithiothreitol, $5 \mu \mathrm{mol} ; \mathrm{KHCO}_{3}, 10 \mu \mathrm{mol} ; \mathrm{NaH}^{14} \mathrm{CO}_{3}, 5 \mu \mathrm{Ci}$; protein, $0.2 \mathrm{mg}$; $\mathrm{NaOH}$ to $\mathrm{pH} 6 \cdot 2$; total volume, I.5 ml. Enzyme preparation was dialysed cell extract.

$\begin{array}{cr}\text { Carbon source }(\mathrm{s}) \text { in growth medium } & \text { Specific radioa } \\ \text { Expt A } & (0.5 \%) \\ \text { Glucose } & 43 \\ \text { Xylose } & 50 \\ \text { Pyruvate } & 129 \\ \text { Glycerol } & 34 \\ \text { Acetate } & 144 \\ \text { Expt B } & \\ \text { Glucose } & 50 \\ \text { Malate } & 285 \\ \text { Aspartate }+ \text { glucose }(0.02 \%) & 212\end{array}$

mediates inhibited the enzyme, the immediate gluconeogenic substrate oxalacetate was stimulatory. As in other micro-organisms (Shrago \& Shug, 1969) and in liver tissue (Seubert, Henning, Schoner \& L'age, 1968), elevated activity of PEPCK was observed under conditions that promote gluconeogenesis and reduced activity occurred when glucose was available. The high level of PEPCK activity when $V$. albo-atrum was grown on pyruvate could be correlated with the formation and decarboxylation of oxalacetate that is generally considered necessary for the conversion of pyruvate to phosphoenolpyruvate (Mahler \& Cordes, I97I). Growth on malate and aspartate could similarly require a high level of cellular PEPCK because both compounds can readily be converted to oxalacetate. The increased synthesis of PEPCK during growth on acetate can be explained by the functioning of the glyoxylate pathway, which again results in the synthesis of oxalacetate through malate. Enzymic evidence indicates the presence of this pathway in V.albo-atrum (Tokunaga et al. 1969). The low level of PEPCK in cells grown on glycerol is also consistent with the gluconeogenic hypothesis since it has been reported that glycerol can be directly metabolized via the Embden-Meyerhof pathway with the formation of phosphoenolpyruvate (Thimann, 1963).

Verticillium albo-atrum has been shown to contain only two $\mathrm{C}_{3}-\mathrm{C}_{4}$ carboxylation enzymes, viz. pyruvate carboxylase and PEPCK (Hartman \& Keen, I973, 1974). The pyruvate carboxylase appears to function in the anaplerotic conversion of $\mathrm{C}_{3}$ compounds to $\mathrm{C}_{4}$ Krebs-cycle intermediates (Hartman \& Keen, 1974), while PEPCK seems to function in gluconeogenesis. The presence of these distinct enzymes would appear consistent with the metabolic flexibility required for growth of the organism on various carbon sources.

\section{REFERENCES}

Hartman, R. E. \& Keen, N. T. (1973). Enzymes capable of anaplerotic carbon dioxide fixation in Verticillium albo-atrum. Phytopathology 63, 947-953.

Hartman, R. E. \& KeEn, N. T. (1974). The pyruvate carboxylase of Verticillium albo-atrum. Journal of General Microbiology 81, 15-19.

Hartman, R. E., Keen, N. T. \& Long, M. (1972). Carbon dioxide fixation by Verticillium albo-atrum. Journal of General Microbiology 73, 29-34. 
Lowry, O. H., Rosebrough, N. T., Farr, A. R. \& Randall, R. J. (I95I). Protein measurement with the Folin phenol reagent. Journal of Biological Chemistry 193, 265-275.

Mahler, H. R. \& Cordes, E. H. (197I ). Biological Chemistry, 2nd. edn, pp. 520-528. New York: Harper \& Row.

Seubert, W., Henning, H. V., Schoner, W. \& L'Age, M. (1968). Effects of cortisol on the levels of metabolites and enzymes controlling glucose production from pyruvate. Advances in Enzyme Regulation 6, $153-187$.

Shrago, E. \& Shug, A. L. (1969). Regulation of phosphoenolpyruvate carboxykinase in Escherichia coli by carbohydrate metabolism. Archives of Biochemistry and Biophysics 130, 393-398.

Thimann, K. V. (1963). The Life of Bacteria, and edn, p. 575. New York: Macmillan.

Tokunaga, J., Malca, I., Sims, J. J., Erwin, D. C. \& KeEn, N. T. (I969). Respiratory enzymes in the spores of Verticillium albo-atrum. Phytopathology 59, I 829-I 832. 